\title{
Effects of mining on the molybdenum absorption and translocation of plants in the Luanchuan molybdenum mine
}

\author{
Kejing Yin ${ }^{1}$, Zhaoyong Shi ${ }^{\text {Corresp., } 1,2,3,4}{ }^{4}$, Mengge Zhang ${ }^{1}$, Yajuan Li ${ }^{1}$ \\ ${ }^{1}$ College of Agriculture, Henan University of Science and Technology, Luoyang, Henan province, China \\ 2 Luoyang Key Laboratory of Symbiotic Microorganism and Green Development, Luoyang, Henan province, China \\ 3 Henan Engineering Research Center of Human Settlements, Luoyang, Henan province, China \\ ${ }^{4}$ Key Laboratory of Mountain Surface Processes and Ecological Regulation, Chengdu, Sichuan Province, China \\ Corresponding Author: Zhaoyong Shi \\ Email address: 9903105@haust.edu.cn
}

Background. There is a critical need to examine whether mining of molybdenum (Mo) ore will affect Mo absorption and translocation by plants at a community level. Methods. Indigenous plants and their rhizospheric soil $(0-20 \mathrm{~cm})$ growing in two different areas including the mining and the unexploited areas were collected from the Luanchuan Mo mine-one of the largest Mo mines in Asia. The concentrations of Mo and other heavy metals of plants or soil were measured by ICP-AES. Mo absorption and translocation in plants growing in two areas were investigated and compared. Heavy metal pollution in soil was also evaluated by the potential ecological hazard index method. Results. Mo concentration in mining soils was higher with the changes from 108.13 to $268.13 \mathrm{mg} \cdot \mathrm{kg}^{-1}$ compared to unexploited area. Mo concentrations in shoots and roots of plants growing in the mining area were also significant higher than those growing in the unexploited area with 2.59 and 2.99 times, respectively. The Mo translocation factor of plants growing in the unexploited area was 1.61, which reached 1.69 times that of plants growing in the mining area. Mo was the main heavy metal pollutant in the soil of both the mining and the unexploited areas. Conclusion. Mining of Mo had changed not only the Mo concentration in soil but also Mo absorption and translocation in plants. Plants growing in the mining area absorbed more Mo from the soil but translocated relatively less to shoots than plants of the unexploited area. However, the mechanisms of Mo absorption and translocation of plants in mining area should be further studied in the future. 


\section{Effects of mining on the molybdenum absorption and}

2 translocation of plants in the Luanchuan molybdenum

3 mine

${ }^{1}$ College of Agriculture, Henan University of Science and Technology, Luoyang, People's

Kejing Yin ${ }^{1,2}$, Zhaoyong Shi ${ }^{1,2,3,4}$, Mengge Zhang ${ }^{1,2,3,4}$ and Yajuan $\mathrm{Li}^{1,2,3,4}$

9 Republic of China

${ }^{2}$ Luoyang Key Laboratory of Symbiotic Microorganism and Green Development, Luoyang,

11 People's Republic of China

${ }^{3}$ Henan Engineering Research Center of Human Settlements, Luoyang, People's Republic of China

${ }^{4}$ Key Laboratory of Mountain Surface Processes and Ecological Regulation, Chinese Academy

18 Zhaoyong Shi,

19 shizy1116@126.com 


\section{ABSTRACT}

Background. There is a critical need to examine whether mining of molybdenum (Mo) ore will affect Mo absorption and translocation by plants at a community level.

Methods. Indigenous plants and their rhizospheric soil $(0-20 \mathrm{~cm})$ growing in two different areas including the mining and the unexploited areas were collected from the Luanchuan Mo mineone of the largest Mo mines in Asia. The concentrations of Mo and other heavy metals of plants or soil were measured by ICP-AES. Mo absorption and translocation in plants growing in two areas were investigated and compared. Heavy metal pollution in soil was also evaluated by the potential ecological hazard index method.

Results. Mo concentration in mining soils was higher with the changes from 108.13 to 268.13 $\mathrm{mg} \cdot \mathrm{kg}^{-1}$ compared to unexploited area. Mo concentrations in shoots and roots of plants growing in the mining area were also significantly higher than those growing in the unexploited area with 2.59 and 2.99 times, respectively. The Mo translocation factor of plants growing in the unexploited area was 1.61, which reached 1.69 times that of plants growing in the mining area. Mo was the main pollutant in soil of both the mining and unexploited areas. Conclusion. Mining of Mo had changed not only the Mo concentration in soil, but also Mo absorption and translocation in plants. Plants growing in the mining area absorbed more Mo from the soil but transferred relatively less to shoots than plants of the unexploited area.

However, the mechanisms of Mo absorption and translocation of plants in mining area should be further studied in the future.

Subjects Plant science, Ecology, Ecotoxicology, Environmental Contamination and Remediation

Keywords Molybdenum mining, Mo concentration, Absorption, Translocation, Soil pollution

\section{INTRODUCTION}

Mo is an important mineral resource, used in metallurgy, chemical industry, aerospace industry, and medicine, among other fields (Li et al., 2009). By the end of 2014, China's molybdenum reserves were 4.3 million tons, accounting for $39.09 \%$ of the world's total. The annual consumption of molybdenum is 75,000 tons in China, accounting for more than one third of the world's total consumption (Zhang et al., 2017). Mining production has increased economic growth in Mo mines, but varying degrees of pollution have been caused by long-term mining activity (Yu et al., 2011; Yu et al., 2012; Wang et al., 2018; Zeng et al., 2019).

Yu et al. (2018) found that the molybdenum content in drinking water of the Luanchuan reservoir reached a level of serious pollution, and the concentration of Mo exceeded the standard limit by 2.44 times. Jia et al. (2015) showed that the Mo concentration is 87 times higher in mining area than unexploited area in Fujian province. Zhang et al. (2019) suggested that Mo mining increased Mo accumulation in adjacent croplands to lead to 3.57 times in rice than that of Mo threshold. In a conclusion, the mining of Mo resulted in accumulation in soils and plants $(Q u$ et al., 2008; Huang et al., 2011). 
69

70

71

72

73

74

75

76

77

78

79

80

81

82

83

84

85

86

87

88

89

90

91

92

93

94

95

96

97

98

99

100

101

102

103

104

105

106

107

The effects of Mo pollution in soil-plant systems has attracted much attention. Many researchers have confirmed that a large amount of exogenous Mo in soil may enhance Mo absorption by plants (Boojar \& Tavakkoli, 2011; Wang et al., 2018; Shi et al., 2018). Boojar \& Tavakkolit (2011) found Mo concentrations in shoots and roots of Achilla tenuifolia were 1769 $\mathrm{mg} \cdot \mathrm{kg}^{-1}$ and $210 \mathrm{mg} \cdot \mathrm{kg}^{-1}$ when Mo concentration in soil reached $448 \mathrm{mg} \cdot \mathrm{kg}^{-1}$. Wang et al. (2018) found Mo concentration in shoots and roots of Macleaya cordata to be as high as $704.4 \mathrm{mg} \cdot \mathrm{kg}^{-1}$ and $398.9 \mathrm{mg} \cdot \mathrm{kg}^{-1}$, respectively, when soil Mo concentration was $256.1 \mathrm{mg} \cdot \mathrm{kg}^{-1}$. Shi et al. (2018) found Mo concentration reached $786.9 \mathrm{mg} \cdot \mathrm{kg}^{-1}$ and $>900 \mathrm{mg} \cdot \mathrm{kg}^{-1}$ in maize shoots and roots, respectively, when $1000 \mathrm{mg} \cdot \mathrm{kg}^{-1} \mathrm{Mo}$ was added to soil. Mo is required in only small amounts by plants to maintain normal growth and development, but chlorosis and yellowing can be caused by excess Mo (Hale et al., 2001; Tow et al., 2016; Niu et al., 2019). At present, there is no clear definition of the toxicity threshold of molybdenum in plants, as different species have different Mo tolerances (Gupta, Chipman \& Mackay, 1978; Huang et al., 2003; McGrath et al., 2010; $\mathrm{Li}$, 2016). Previous studies found that the threshold of Mo poisoning was $192 \mathrm{mg} \cdot \mathrm{kg}^{-1}$ in Trifolium pretense (Gupta, Chipman \& Mackay, 1978), 100-200 $\mathrm{mg} \cdot \mathrm{kg}^{-1}$ in Lactuca sativa (Gupta, Chipman \& Mackay, 1978) and Solanum tuberosu (McGrath et al., 2010), $500 \mathrm{mg} \cdot \mathrm{kg}^{-1}$ in Triticum aestivum ( $\mathrm{Li}, 2016), 640 \mathrm{mg} \cdot \mathrm{kg}^{-1}$ in Brassica oleracea (Gupta, Chipman \& Mackay, 1978), and more than $1000 \mathrm{mg} \cdot \mathrm{kg}^{-1}$ in Lycopersicon esculentum (Huang et al., 2003).

Different translocation mechanisms could be used by plants to resist excess Mo (Kádár, Koncz \& Gulyás, 2000; Lian, Xu \& Han, 2011; Kovács et al., 2015). Kádár, Koncz \& Gulyás (2000) found maize can absorb appreciable quantities of Mo from the soil by roots, but Mo translocated from roots to shoots decreased with the increase of Mo concentration in soil. Similar results were also found by Kovács et al. (2015). Lian, Xu \& Han (2011) found Phragmites australis stored Mo in roots and transferred little Mo to shoots, but Typha orientalis translocated large quantities of Mo from roots to shoots.

Although extensive Mo mining has created great material wealth in some areas, negative effects of Mo pollution on local soil-plant systems may be substantial (Haque et al., 2008; Boojar \& Tavakkoli, 2011). There are few studies about Mo absorption and translocation of indigenous plants growing in Luanchuan. Further, many researchers have focused on Mo absorption and translocation of cultivated plants (Gupta, Chipman \& Mackay, 1978; McGrath et al., 2010; Kovács et al., 2015), and whether Mo mining activity will increase Mo absorption of single or a few chosen species (Boojar \& Tavakkoli, 2011; Wang et al., 2018). It is unclear how molybdenum mining will affect Mo absorption and translocation for entire indigenous plant communities.

In this paper, we sampled indigenous plants growing in a mining area $(400 \mathrm{~m}$ around the center of the mining area) and an unexploited and proven mining area $(2000 \mathrm{~m}$ from the edge of an unexploited molybdenum mine) of the largest molybdenum mine of Asia. Mo absorption and translocation of plants growing in the mining and the unexploited areas were compared, which would provide a scientific basis for ecological restoration and vegetation reconstruction of this

Peer) reviewing PDF | (2019:12:44130:1:2:NEW 8 Apr 2020) 
108

109

110

111

112

113

114

115

116

117

118

119

120

121

122

123

124

125

126

127

128

129

130

131

132

133

134

135

136

137

138

139

140

141

142

143

144

145

146

147

and similar mine areas. Therefore, our hypothesis is that mining of Mo will increase Mo concentration in soil, which lead to Mo accumulation in plants.

\section{MATERIALS \& METHODS}

\section{Study area}

In Luanchuan County $\left(33^{\circ} 46^{\prime} \mathrm{N}, 111^{\circ} 37^{\prime} \mathrm{E}\right)$, reserves of molybdenum mines are 2.06 million tons, ranking first in Asia and third in the world (Wang \& Tian, 2000; Zeng et al., 2013). The development of molybdenum mining in Luanchuan began in 1960 (Wang \& Tian, 2000). There are 27 open pit mines, 9 mines are still in production, and quantities of daily mining can reach 13,000 tons (Wang \& Tian, 2000; Huo, Yang \& Zhang, 2007; Zeng et al., 2013). To confirm whether mining will affect Mo absorption and translocation in plants or not, we selected two representative areas in the Luanchuan molybdenum mine area for this study. The mining area $\left(33^{\circ} 53^{\prime}-33^{\circ} 55^{\prime} \mathrm{N}, 111^{\circ} 27^{\prime}-111^{\circ} 29^{\prime} \mathrm{E}\right)$ was located at the edge of the central mining area (around $400 \mathrm{~m}$ away from the center of the mining area), and it had been affected by mining, but the ground was still covered with vegetation. Mo reserves are 1.33 million tons in the central mining area with the mining quantities of 5000 tons per day (Wang \& Tian, 2000). The unexploited area $\left(33^{\circ} 48^{\prime}-33^{\circ} 53^{\prime} \mathrm{N}, 111^{\circ} 27^{\prime}-111^{\circ} 30^{\prime} \mathrm{E}\right)$ was located in a proved and not mining Mo mine, which are away from more than $2000 \mathrm{~m}$ of the edge mining area.

\section{Sample collection}

Sample belts were established in the mining and the unexploited Mo mine areas.. In each sample belt, five $20 \times 20 \mathrm{~m}$ plots were set with 50-100 m apart. At every sample plot, plants were identified and recorded into species by a botanist (Five mature individuals of each plant species were collected if the number of a plant species was more than 5; Table 1). Plant species were identified as dominant when the number of times of appearance of each species was greater or equal to 3 in all five plots of each study area. Of the plant species in the mining area, 22 plant species are collected, which belong to 18 genera of 10 families (Table 1). As far as the unexploited area is concerned, 23 plant species belonging to 20 genera and 9 families were recorded (Table 1). The nine shared species are observed in the mining and the unexploited areas including Ailanthus altissima, Artemisia argyi, Artemisia capillaris, Lespedeza bicolor, Phragmites australis, Poa annua, Robinia pseudoacacia, Setaria viridis, Sorghum propinquum, which reach $41 \%$ and $39 \%$ of total plant species in the mining and the unexploited areas. The dominant herbaceous plants in both the mining and the unexploited areas are the familis of Gramineae and Compositae, while the dominant family of woody plants is Leguminosae. When the plant communities are considered, herbaceous in the families of Gramineae and Compositae are dominant in two areas. Further, during our investigation, Lespedeza bicolor and Setaria viridis are dominant plant species in either mining or unexploited areas. Additionally, corresponding rhizosphere soil $(0-20 \mathrm{~cm})$ from each species was collected and mixed into a single soil sample for each plot.

\section{Table 1 The shared species and endemic species in the mining area and the unexploited area.}


148 Measurement and calculation of heavy metals in soil and plants

149 Soil samples were air-dried at room temperature and sieved through $2 \mathrm{~mm}$ filters to remove

150 plant roots and other material before analysis. The plant samples were cut into shoots and roots, 151 they were carefully washed with deionized water and oven-dried at $105^{\circ} \mathrm{C}$ for $30 \mathrm{~min}$ and $60^{\circ} \mathrm{C}$

152 for $72 \mathrm{~h}$, then ground into a fine powder, and sieved through $1 \mathrm{~mm}$ nylon sieve. Concentrations

153 of $\mathrm{Mo}, \mathrm{Cu}, \mathrm{Mn}$, and $\mathrm{Zn}$ were determined by ICP-AES (Agilent 720, California, USA).

154 Total nitrogen (STN), total phosphorus (STP), and organic matter (SOM) of soil were

155

156

157

158

159

160

161

162

163

164

165

166

167

168

169

170

171

172

173

174 measured according to the methods of Bao (2000). The STN in the mining area and the unexploited area were 0.34 and $1.40 \mathrm{~g} \cdot \mathrm{kg}^{-1}$, respectively. The STP were 0.75 and $0.79 \mathrm{~g} \cdot \mathrm{kg}^{-1}$, respectively. The SOM were 17.47 and $22.16 \mathrm{~g} \cdot \mathrm{kg}^{-1}$, respectively.

The potential ecological risk index was used to assess heavy metal pollution in soils (Hakanson, 1980). The potential ecological risk index of a heavy metal is $\mathrm{E}_{\mathrm{i}}=\mathrm{T}_{\mathrm{i}} \times \mathrm{C}_{\mathrm{i}} \cdot \mathrm{T}_{\mathrm{i}}$ is the toxic coefficient of heavy metals: $\mathrm{Cu}=5$ (Xu et al., 2008), $\mathrm{Mn}=\mathrm{Zn}=1$ (Xu et al., 2008), and Mo $=15\left(\right.$ Liu, 2009); $\mathrm{C}_{\mathrm{i}}$ is the ratio of metal concentration in study area to the corresponding soil background value in China (Wei et al., 1991). The total potential ecological risk index of multiple heavy metals is $\mathrm{RI}=\sum \mathrm{E}_{\mathrm{i}}$. Evaluation criteria from Hakanson (1980) were followed. To assess Mo translocation in plants, a translocation factor (TF) was used. TFs were calculated as follows: $\mathrm{TF}=$ Concentration of Mo in shoots/ Concentration of Mo in roots (Kisku, Barman \& Bhargava, 2000).

\section{Statistical Analysis}

Heavy metal concentrations in the mining and the unexploited areas were compared using t-tests, and a value of $P \leq 0.05$ was considered significant. A t-test was also employed to compare the difference in Mo absorption and translocation of plants growing in the mining and the unexploited areas at $P \leq 0.05$. Linear regression was used to assess the relationship of Mo concentration between roots and shoots of plants. All analyses were conducted in SPSS 21.0 (Chicago, USA).

\section{RESULTS}

\section{Heavy metal concentration and potential ecological risk assessment}

Four heavy metals of $\mathrm{Mo}, \mathrm{Cu}, \mathrm{Mn}$ and $\mathrm{Zn}$ were considered due to their higher concentration than others. Concentrations of $\mathrm{Mo}, \mathrm{Cu}$, and $\mathrm{Mn}$ were significantly higher in the mining area with values of $268.13 \mathrm{mg} \cdot \mathrm{kg}^{-1}, 136.45 \mathrm{mg} \cdot \mathrm{kg}^{-1}$, and $1282.46 \mathrm{mg} \cdot \mathrm{kg}^{-1}$ than in the unexploited area, respectively (Table 2). The $\mathrm{Zn}$ concentration was $456.22 \mathrm{mg} \cdot \mathrm{kg}^{-1}$ in the mining area compared to $370.70 \mathrm{mg} \cdot \mathrm{kg}^{-1}$ in the unexploited area. These results indicated that Mo mining had increased $2.48,2.14,1.36$, and 1.23 times of $\mathrm{Mo}, \mathrm{Cu}, \mathrm{Mn}$, and $\mathrm{Zn}$ concentration in mining soil than unexploited soils, respectively. Concentrations of the four heavy metals in the mining and highest was Mo, which was 134.07 times higher in the mining area and 54.07 times higher in the 
187

188

189

190

191

192

193

194

195

196

197

198

199

200

201

202

203

204

205

206

207

208

209

210

211

212

213

214

215

216

217

218

219

220

221

222

223

224

225

226

227

228

229

230

231

unexploited areas were greater than second grade thresholds set by the State Environmental Protection Administration for Soil Protection in China (GB15618-1995).

Table 2 Soil heavy metal concentrations $\left(\mathbf{m g} \cdot \mathrm{kg}^{-1}\right)$ in the mining and the unexploited areas.

Notes:

Different letters after the values of each column represent significant difference at $P<0.05$ level, according to t-test.

${ }^{a}$ second-grade threshold of the Environmental Quality Standard for Soils in China (GB15618-1995).

${ }^{\mathrm{b}}$ Soil background values of China (Wei et al., 1991).

The $\mathrm{E}_{\mathrm{i}}$ value of Mo reached 2010.98 and 810.97 in the mining and the unexploited areas, respectively, which indicated soils had been extremely contaminated by Mo on the basis of the evaluation criteria established by Hakanson (1980). All Ei values of $\mathrm{Cu}, \mathrm{Mn}$, and $\mathrm{Zn}$ were less than 40 in both mining and unexploited area, indicating that soils were slightly contaminated by them. Further, Mo accounted for $98.12 \%$ and $97.54 \%$ of the total potential ecological risk indexes of the mining and the unexploited area according to the Ei value, respectively (Table 3). Overall, Mo is the main pollutant in both the mining and the unexploited area in soils of Luanchuan molybdenum mine areas.

\section{Table 3 The potential soil ecological risk indexes of heavy metals in Luanchuan molybdenum mine area. Notes: \\ The values in brackets represent the risk index of a single heavy metal as a percentage of the total risk index.}

\section{Mo concentration of plants}

Mo concentrations of shoots and roots were higher with the averages of 124.02 and 131.30 $\mathrm{mg} \cdot \mathrm{kg}^{-1}$ in the mining area compared to 47.80 and $43.92 \mathrm{mg} \cdot \mathrm{kg}^{-1}$ in the unexploited area, respectively (Fig. 1). Mo concentration in roots and shoots of herbaceous plants growing in the mining area increased significantly by 3.58 and 2.27 times, respectively, compared to that in the unexploited area (Fig. 2). When the dominant plant species were considered, Mo concentration in roots and shoots of Lespedeza bicolor and Setaria viridis were significantly higher in the mining area than them in the unexploited area, respectively (Fig. 3). Our results indicated enhancement of Mo in roots and shoots of plants had been caused by mining activity of Mo mine.

Figure 1. Mo concentration of plants growing in the mining and the unexploited areas. Values represent mean \pm standard error (SE), the same as below. * above bars indicate significant differences between the same organs in plants for different areas at $P<0.05$, according to the t-test.

Figure 2. Mo concentration of different life forms of plants growing in the mining and the unexploited areas. * above bars indicate significant differences between the same organs in the same plant life forms for different areas at $P<0.05$, according to the t-test.

Figure 3. Mo concentration of dominant species growing in the mining and the unexploited areas. * above bars indicate significant differences between the same organs in the same species for different areas at $P<0.05$, according to the t-test. 
232 Mo translocation in plants

233 As shown by a t-test (Fig. 4), the Mo translocation factor of plants growing in the mining area

234 was significantly lower with 0.95 compared to 1.61 in the unexploited area. Mo translocation in

235 herbaceous plants growing in the mining area reduced significantly by $48.37 \%$, compared to that

236 in the unexploited area (Fig. 5). Similar trends were also observed in Mo translocation of

237 Lespedeza bicolor and Setaria viridis growing in the mining area compared to the unexploited

238 area, 0.95 compared to 2.18 and 1.02 compared to 2.07, respectively (Fig. 6). These results

239 showed that Mo translocation of plants decreased with increasing Mo concentration in soil.

240

241

242

243

244

245

246

247

248

249

250

251

252

253

254

255

256

257

258

Figure 4. Mo translocation of plants growing in the mining and the unexploited areas. * above bars indicate significant differences between the plants for different areas at $P<0.05$, according to the t-test.

Figure 5. Mo translocation of different life forms of plants growing in the mining and the unexploited areas. * above bars indicate significant differences between the same organs in the same plant life forms for different areas at $P<0.05$, according to the t-test.

Figure 6. Mo translocation of dominant species growing in the mining and the unexploited areas. * above bars indicate significant differences between the same organs in the same species for different areas at $P<0.05$, according to the t-test.

\section{Relationship of Mo between plant shoots and roots}

The Mo concentration of shoot increased linearly with the enhancement of Mo concentration in roots (Fig. 7), which indicated that the distribution Mo in shoots and roots are determined by the root absorption. Further, the changing trends of Mo concentration in shoots with variation of roots are similar between the mining and the unexploited areas.

Figure7. The relationship between shoot Mo and root Mo in plants. (a) Mining area; (b) Unexploited area.

259

260

261

262

263

264

265

266

267

268

269

270

271

272

\section{DISCUSSION}

Usually, mining activity of Mo could affect the soil Mo concentration (Haque et al., 2008). In this study, Mo concentrations in the mining area reached $268.13 \mathrm{mg} \cdot \mathrm{kg}^{-1}$ (Table 2), 2.48 times that in unexploited area, and 134.1 times the soil background value in China $\left(2 \mathrm{mg} \cdot \mathrm{kg}^{-1}\right.$, Wei et al., 1991). This result showed that long-term mining activity had led to the enrichment of Mo in soil, which agrees with the previous findings. Han et al. (2019) confirmed that the Mo concentration reached 14.4 times the soil background value in Shaanxi Province because of the mining activity. Boojar \& Tavakkoli (2011) demonstrated that Mo mining has resulted in a massive increase Mo concentration of soil and the mean concentration of Mo in the mining soil reached $448 \mathrm{mg} \cdot \mathrm{kg}^{-1}$. Similar results have been reported in other studies (Battogtokh, Lee \& Woo, 2014; Tapia et al., 2018; Pipoyan et al., 2019). Further, Wang \& Tian (2000) has confirmed that the associated heavy metal minerals with Mo in the Luanchuan molybdenum ore mainly include $\mathrm{Cu}, \mathrm{Mn}$ and $\mathrm{Zn}$. It is inevitable the long-term mining activity also caused the increase of $\mathrm{Cu}, \mathrm{Mn}$, and $\mathrm{Zn}$ in soil. Similar results have also been reported in the research of Han

Peer) reviewing PDF | (2019:12:44130:1:2:NEW 8 Apr 2020) 
273 et al. (2019), who found Mo mining could not only increase the Mo concentration, but also

274 increase the concentrations of the associated heavy metals such as $\mathrm{Cu}, \mathrm{Pb}$, and $\mathrm{Zn}$ in Shaanxi Mo

275 mine area. Mo concentration in the unexploited area was $108.13 \mathrm{mg} \cdot \mathrm{kg}^{-1}, 54.1$ times higher than

276 the background values (Table 2). The possible reason for the higher Mo in the unexploited area

277 than soil background value is that Mo ore bodies in Luanchuan are shallow and exposed on the

278 surface, which had been testified and showed suitable for large-scale, open pit mining (Wang \&

279 Tian, 2000; Zeng et al., 2013). The potential ecological risk assessment showed that the RI value

280 in the mining area was as high as 2049.45, with the Mo Ei values of the mining area accounting

281 for $98.12 \%$ of total potential ecological risk. These results suggest that Mo is the main pollutant

282 in Luanchuan molybdenum mines.

283 The investigation of plant communities in the Luanchuan Mo mine area showed that plant

284 communities are dominated by herbaceous Gramineae and Compositae both the mining and the

285

286

287

288

289 unexploited areas (Table 1). This result indicated that herbaceous plants are more adaptable to the harsh environment of the mine area than woody plants, which consistent with the findings of Xue et al. (2014) who found that herbaceous plants have a higher resistance to environmental changes and they may play a dominant role in the plant community of mine areas. Meantime, we also found woody plants in both areas are dominated by Leguminosae, as these plants are likely

290

291

292

293

294

295

296

297

298

299

300

301

302

303

304

305

306

307

308

309

310

311 to form a symbiotic relationship with rhizobia than woody of other families. This improves the nutrient acquisition capacity of Leguminosae and enhances their ability to persist in harsh environments (Zahran, 1999; Reed SC, 2017).

Generally, plants have a strong Mo tolerance, and most have no adverse reactions even when Mo concentration is greater than $100 \mathrm{mg} \cdot \mathrm{kg}^{-1}$ (Gupta, Chipman \& Mackay, 1978; Huang et al., 2003; McGrath et al., 2010; Li, 2016; Shi et al., 2018). Boojar \& Tavakkoli (2011) found that plants such as Achilla tenuifolia and Erodium ciconium could grow normally at the Sanj molybdenum mine, where the concentration of Mo in soil was $448 \mathrm{mg} \cdot \mathrm{kg}^{-1}$. In our previous maize culture pot experiment, we found maize could grow normally when $1000 \mathrm{mg} \cdot \mathrm{kg}^{-1} \mathrm{Mo}$ was added to soil (Shi et al., 2018). In the present study, Mo concentration in the Luanchuan Mo mine area exceeded normal ranges, which would generally be considered poisonous to plants, but no Mo toxic symptoms were observed for indigenous plants. This suggested that indigenous plants growing in the Luanchuan molybdenum mine area may have a strong adaption to Mo.

Mining not only leads to the enrichment of Mo in soil but also caused an increase of Mo concentration in plant tissues (Haque et al., 2008). In this paper, Mo concentrations in the roots and shoots of plants growing in the mining area were $131.30 \mathrm{mg} \cdot \mathrm{kg}^{-1}$ and $124.02 \mathrm{mg} \cdot \mathrm{kg}^{-1}$, respectively, significantly higher than that in the same tissues of plants growing in the unexploited area (Fig. 1). Mo concentrations of Lespedeza bicolor and Setaria viridis growing in the mining area were significantly higher than that in the same plant species growing in the unexploited area (Fig. 3). A linear correlation indicated Mo in shoots increased with the concentration in roots (Fig. 7), which was similar to a previous study that indicated Mo addition significantly increased Mo concentrations in both shoots and roots of plants (Shi et al., 2018). 
312 Overall, these results indicated mining had led to an increase of Mo absorption in plants, 313 which is consistent with previous researches. Wang et al. (2018) observed mining resulted in the 314 Mo concentration to $772.4 \mathrm{mg} \cdot \mathrm{kg}^{-1}$ in the shoots of Morus australis, which was 154 times than 315 the contents in the plants growing unexploited area. Boojar \& Tavakkoli (2011) revealed that Mo 316 concentrations were greater than normal ranges in 36 plant species growing in a mining area, 317 among which Achilla tenuifollia was the highest with $1979 \mathrm{mg} \cdot \mathrm{kg}^{-1}$. Kumar \& Singh (1980) 318 found there is a synergistic relationship between Mo and sulfur (S) when the Mo supply level in 319 soil is high. The main chemical composition of the Luanchuan molybdenum ore is $\mathrm{MoS}_{2}$ and the 320 mining of Mo ore may cause exogenous S to enter the soil. Due to the high Mo concentration in the mining soil, $\mathrm{S}$ may play a major role in promoting the Mo absorption of plants. This is one possible reason that the Mo concentrations of plants growing in the mining area were significantly higher than that of plants growing in the unexploited area. In addition, no certain relationship on Mo concentration between soil and plant was observed (Fig. S1), which supported the previous findings ( $\mathrm{Li}$, 2016; Shi et al., 2018). Shi et al. (2018) showed Mo concentration in the shoots of maize was significantly lower in $2000 \mathrm{mg} \cdot \mathrm{kg}^{-1}$ Mo treatment than treatments with 1000 and $4000 \mathrm{mg} \cdot \mathrm{kg}^{-1} \mathrm{Mo}$ when plants were inoculated with arbuscular mycorrhizal fungi (AMF). But Mo concentration in the shoots and roots of maize did not change significantly with the increase of soil Mo concentration under or without AMF inoculation. $L i$ (2016) revealed that Mo concentration in the shoots of two winter wheat varieties (Mo efficient and inefficient varieties) did not increase significantly as soil Mo concentration increased from 0.15 to $1000 \mathrm{mg} \cdot \mathrm{kg}^{-1}$, while Mo concentration in roots increased significantly when soil Mo concentration increased from 500 to $1000 \mathrm{mg} \cdot \mathrm{kg}^{-1}$. He also found Mo concentration of the grain in Mo efficient variety increased significantly as soil Mo concentration increased from 500 to $1000 \mathrm{mg} \cdot \mathrm{kg}^{-1}$, but no significant increase in Mo inefficient variety. These results indicated that the relationship on Mo concentration between soil and plant may be affected by other factors such as soil microorganisms and plant species, which need to be studied further.

It has been testified that Mo translocation have huge range of changes in plants with environments and plant species (Kádár, Koncz \& Gulyás, 2000; Haque et al., 2008; Lian, Xu \& Han, 2011; Kovács et al., 2015; Qin et al. 2017; Ameh, Omatola \& Akinde, 2019; Couto et al., 2019; Wang, Liu \& Qin,2019). Kovács et al. (2015) found the Mo translocation factor of maize decreased from 0.85 to 0.48 when adding $270 \mathrm{mg} \cdot \mathrm{kg}^{-1}$ of Mo to the soil. Lian, Xu \& Han (2011) found the Mo translocation factors of Typha orientalis growing in nutrient solution with Mo concentrations $0-20 \mathrm{mg} \cdot \mathrm{L}^{-1}$ were always higher than 1 , but the Mo translocation factors of Phragmites australis under the same Mo concentrations were always lower than 1. In our study, the Mo translocation factor of plants growing in the unexploited area was significantly higher than that in the mining area (Fig. 4), indicating the distribution of Mo in plant tissues changed with Mo concentrations in soil. Significantly lower Mo transolcation from roots to shoots was also found in herbaceous plants growing in the mining area (Fig. 5). Mo translocation in woody plants and dominant plant species both showed declining trends with increasing Mo concentrations in soil, although no significant differences were observed (Figs. 5 and 6). These 
352

353

354

355

356

357

358

359

360

361

362

363

364

365

366

367

368

369

370

371

372

373

374

375

376

377

378

379

380

381

382

383

384

385

386

387

388

389

390

results indicated plants growing in different areas likely have different translocation strategies to resist excess Mo. To reduce toxicity of molybdenum to plants' physiological systems, plants growing in the mining area absorbed large amounts of Mo and stored it in their roots. In the unexploited area, Mo concentration in soil was relatively low, and plants growing in this area could absorb a large amount of Mo from soil and translocate it from roots to shoots.

The significant differences of Mo absorption and translocation in Figs. 2 and 4 between herbaceous and woody plants in the mining and unexploited areas may be explained by plant life form because previous studies found that different life form of plants have unequal absorption and translocation to excess Mo (Gupta, Chipman \& Mackay, 1978; Huang et al., 2003; McGrath et al., 2010; $L i, 2016$ ). As to herbaceous plants, the marked variation in plant absorption and translocation of Mo between the mining and the unexploited areas may be determined by the responses of herbaceous plant to increase of Mo in soils. Shi et al. (2018) confirmed that Mo absorption and translocation of maize were significantly different under different Mo concentrations. Mo concentration in shoot and root of maize increased significantly 91.79 and $324.60 \mathrm{mg} \cdot \mathrm{kg}^{-1}$, respectively, but the Mo translocation in maize reduced significantly by $51.55 \%$, when the soil Mo concentration increased from 2000 to $4000 \mathrm{mg} \cdot \mathrm{kg}^{-1}$. Similar results were also observed in winter wheat by $\mathrm{Li}$ (2016). However, the translocation of Mo in woody species is not significant difference between the mining and the unexploited areas, which is possibly correlated with plant characteristics and different elements. Zeng (2017) showed that the $\mathrm{Cu}$ translocations of the woody Albizia kalkora and Sophora japonica decreased with increase of $\mathrm{Cu}$ in soils based on four Cu levels, but Albizia julibrissin presented the opposite trend. Wang et al. (2018) also studied the translocation of four woody plants to $\mathrm{Pb}$ and $\mathrm{Zn}$, which indicated that the translocations factors changed with woody plant species, element concentration and different elements. Therefore, we speculate that woody plants transfer Mo may be varied with plant species. Certainly, this needs to be further explored.

Many experiments have found that most plants not only have strong Mo tolerance but also have strong Mo accumulation capacity (Huang et al., 2003; Tow et al., 2016; Shi et al., 2018; Wang et al. 2018). Huang et al. (2003) found Lycopersicon esculentum only presented chlorosis and yellowing when the Mo concentration in the shoots was as high as $1000 \mathrm{mg} \cdot \mathrm{kg}^{-1}$. Tow et al. (2016) revealed the highest Mo concentration in yellow and green leaves of Axonopus compressus achieved 6050 and $1393 \mathrm{mg} \cdot \mathrm{kg}^{-1}$, respectively. In the present study, Mo concentration in shoots of Setaria viridis growing in the mining area was $164.69 \mathrm{mg} \cdot \mathrm{kg}^{-1}$, far higher than the normal Mo concentration in plants, indicating Setaria viridis has a strong ability to absorb Mo, which is similar to the findings of McGrath et al. (2010) and Shi et al. (2018). Slopes of the correlation of Mo between roots and shoots were not the same as for the Mo translocation factor of plants growing in the two areas. This may be caused by different plant communities or to different mechanisms of plant responses to Mo when Mo concentrations are enhanced in soils. Specific factors that cause such differences need to be further studied.

\section{Conclusions}

Peer) reviewing PDF | (2019:12:44130:1:2:NEW 8 Apr 2020) 
391

392

393

394

395

396

397

398

399

400

401

402

403

404

405

406

407

408

409

410

411

412

413

414

415

416

417

418

419

420

421

422

423

424

425

426

427

428

429

Mining of Mo has resulted in the importation of large quantities of $\mathrm{Mo}, \mathrm{Cu}, \mathrm{Mn}$ and $\mathrm{Zn}$ into soils. The concentrations of $\mathrm{Mo}, \mathrm{Cu}, \mathrm{Mn}$ and $\mathrm{Zn}$ in mining soil were 2.48, 2.14, 1.36 and 1.23 times of that in unexploited soil, respectively. The pollution assessment indicated that Mo was the main pollutant in both mining and unexploited soils of the Luanchuan mine area.

Mining of Mo increased the absorption and decreased the translocation of Mo in indigenous plants. The Mo concentrations in the shoots and roots in mining area are 2.59 and 2.99 times than them in unexploited area. The decrease of translocation in plant to Mo is mainly led by herbaceous species. The changes of Mo concentrations in soil are easier to cause the feedbacks of Mo translocation in herbaceous than woody plants.

This is the first study to investigate the effect of Mo mining of Mo absorption and translocation based on the indigenous plants in our knowledge. Our study will benefit for selecting suitable plants for phytoremediation of Mo contaminated soils. Additionally, further studies are needed to find out the specific relationship between soil Mo and plant Mo.

\section{Funding}

Funding statement: This research was funded by Program for Science \& Technology Innovation Talents in Universities of Henan Province (18HASTIT013), NSFC (31670499), Scientific and technological research projects in Henan province (192102110128), Key Laboratory of Mountain Surface Processes and Ecological Regulation, CAS (20160618), Laboratory for Earth Surface Processes, Ministry of Education (201612), the Innovation Team Foundation (2015TTD002) of Henan University of Science and Technology.

\section{References}

Ameh EG, Omatola OD, Akinde SB. 2019. Phytoremediation of toxic metal polluted soil: Screening for new indigenous accumulator and translocator plant species, northern Anambra Basin, Nigeria. Environmental Earth Sciences 78: 345 DOI 10.1007/s12665-019$8343-8$.

Bao SD. 2000. Soil agrochemical analysis. Beijing: China Agriculture Press.

Battogtokh B, Lee JM, Woo N. 2014. Contamination of water and soil by the Erdenet copper-molybdenum mine in Mongolia. Environmental Earth Sciences 71: 3363-3374 DOI 10.1007/s12665-013-2727-y.

Boojar MMA, Tavakkoli Z. 2011. New molybdenum-hyperaccumulator among plant species growing on molybdenum mine-a biochemical study on tolerance mechanism against metal toxicity. Journal of Plant Nutrition 34: 1532-1557 DOI 10.1080/01904167.2011.585209.

\section{Couto CMCM, Ribeiro C, Ribeiro AR, Maia A, Santos M, Tiritan ME, Pinto E, Almeida} AA. 2019. Spatiotemporal distribution and sources of trace elements in Ave river (Portugal) lower basin: Estuarine water, sediments and indigenous flora. International Journal of Environmental Research 13: 303-318 DOI 10.1007/s41742-019-00174-z.

Gupta UC, Chipman EW, Mackay DC. 1978. Effects of molybdenum and lime on the yield and molybdenum concentration of crops grown on acid sphagnum peat soil. Canadian Journal of Plant Science 58: 983-992 DOI 10.4141/cjps78-151. 
430

431

432

433

434

435

436

437

438

439

440

441

442

443

444

445

446

447

448

449

450

451

452

453

454

455

456

457

458

459

460

461

462

463

464

465

466

467

468

469

Hakanson L. 1980. An ecological risk index for aquatic pollution control: a sediment logical approach. Water Research 14: 975-1001 DOI 10.1016/0043-1354(80)90143-8.

\section{Hale KL, McGrath SP, Lombi E, Stack SM, Terry N, Pickering IJ, George GN, Pilon-} Smits EAH. 2001. Molybdenum sequestration in Brassica species. A role for anthocyanins? Plant Physiology 126: 1391-1402 DOI 10.2307/4280014.

Han ZX, Wan DJ, Tian HX, He WX, Wang ZQ, Liu Q. 2019. Pollution assessment of heavy metals in soils and plants around a molybdenum mine in central China. Polish Journal of Environmental Studies 28: 123-133 DOI 10.15244/pjoes/83693.

Haque N, Peralta-Videa JR, Jones GL, Gill TE, Gardea-Torresdey JL. 2008. Screening the phytoremediation potential of desert broom (Baccharis sarothroides Gray) growing on mine tailings in Arizona, USA. Environmental Pollution 153: 362-368 DOI 10.1016/j.envpol.2007.08.024.

Huang J, Wu JL, Li TJ, Song XM, Zhang BZ, Zhang PW, Zheng XY. 2011. Effect of exposure to trace elements in the soil on the prevalence of neural tube defects in a high-risk area of China. Biomedical and Environmental Sciences 24: 94-101 DOI 10.3967/08953988.2011.02.002.

Huang JG, Zhang NM, Li XF, Yuan L. 2003. Plant nutrition. Beijing: China Forestry Press. Huo MS, Yang JY, Zhang X. 2007. Development present situation of molybdenum ore in China and disposal of tailings. Express Information of Mining Industry 8: 1-3.

Jia T, Jia YY, Yu SJ, Jiang ZL, Chen YH. Wang, G. 2015. Pollution of molybdenum and heavy metals of the soils and rice near a molybdenum mining site in eastern Fujian. Environmental Monitoring in China 31, 45-49 DOI 10.3969/j.issn.1002-6002.2015.01.009.

Kádár I, Koncz J, Gulyás F. 2000. Effect of microelement loads on the composition of maize and the readily available soil nutrient content on a calcareous chernozem. Agrokém. és Talajt 49: $205-220$.

Kisku GC, Barman SC, Bhargava SK. 2000. Contamination of soil and plants with potentially toxic elements irrigated with mixed industrial effluent and its impact on the environment. Water Air and Soil Pollution 120: 121-137 DOI 10.1023/a:1005202304584.

Kovács B, Puskás-Preszner A, Huzsvai L, Lévai L, Bódi É. 2015. Effect of molybdenum treatment on molybdenum concentration and nitrate reduction in maize seedlings. Plant Physiology and Biochemistry 96: 38-44 DOI 10.1016/j.plaphy.2015.07.013.

Kumar V, Singh M. 1980. Sulfur, phosphorus, and molybdenum interactions in relation to growth, uptake, and utilization of sulfur in soybean. Soil Science 129(5):297-304 DOI 10.1097/00010694-198005000-00006.

Li L. 2016. The response characteristics of winter wheat to molybdenum pollution in soil and mechanisms for resistance. Master Thesis, Huazhong Agricultural University.

Li N, Chen YJ, Ni ZY, Hu HZ. 2009. Characteristics of ore-forming fluids of the Yuchiling porphyry Mo deposit, Songxian county, Henan province, and its geological significance. Acta Petrologica Sinica 25: 2509-2522.

Lian JJ, Xu SG, Han CW. 2011. Absorption characteristics of molybdenum by reed and cattail.

Peer) reviewing PDF | (2019:12:44130:1:2:NEW 8 Apr 2020) 
470

471

472

473

474

475

476

477

478

479

480

481

482

483

484

485

486

487

488

489

490

491

492

493

494

495

496

497

498

499

500

501

502

503

504

505

506

507

508

Lin LQ. 2009. Application of toxicological safety assessment data to calculate the toxicity coefficient of heavy metals. Papers on heavy metal pollution monitoring, risk assessment and remediation technology symposium, Beijing. 57-60.

McGrath SP, Micó C, Zhao FJ, Stroud JL, Zhang H, Fozard S. 2010. Predicting molybdenum toxicity to higher plants: Estimation of toxicity threshold values. Environment Pollution 158: 3085-3094 DOI 10.1016/j.envpol.2010.06.030.

Niu C, Jiang M, Li N, Cao JG, Hou MF, Ni DA, Chu ZQ. 2019. Integrated bioinformatics analysis of $\mathrm{As}, \mathrm{Au}, \mathrm{Cd}, \mathrm{Pb}$ and $\mathrm{Cu}$ heavy metal responsive marker genes through Arabidopsis thaliana GEO datasets. Peer J 7: e6495 DOI 10.7717/peerj.6495.

Pipoyan D, Stepanyan S, Stepanyan S, Beglaryan M, Merendino N. 2019. Health risk assessment of potentially toxic trace and elements in vegetables grown under the impact of Kajaran mining complex. Biological Trace Element Research 192: 336-344 DOI 10.1007/s12011-019-01675-w.

Qin SY, Sun XC, Hu CX, Tan QL, Zhao XH, Xu SJ. 2017. Effects of tungsten on uptake, transport and subcellular distribution of molybdenum in oilseed rape a two different molybdenum levels. Plant Science 256: 87-93 DOI 10.1016/j.plantsci.2016.12.009.

Qu J, Yuan X, Cong Q, Zhang H. 2008. Analysis and assessment on the pollution condition of heavy metals in the soil in the farmland around the collection areas of molybdenum ore. Ecology and Environment 17: 677-681.

Reed SC. 2017. Disentangling the complexities of how legumes and their symbionts regulate plant nitrogen access and storage. New Phytologist 213: 478-480 DOI 10.1111/nph.14390.

Shi ZY, Zhang JC, Wang FY, Li K, Yuan WK, Liu JB. 2018. Arbuscular mycorrhizal inoculation increases molybdenum accumulation but decreases molybdenum toxicity in maize plants grown in polluted soil. RSC Advance 8: 37069-37076 DOI $10.1039 / \mathrm{c} 8 \mathrm{ra} 07725 \mathrm{~h}$.

State Environmental Protection Administration of China. 1995. Chinese environmental quality standard for soils.

Tapia JS, Valdes J, Orrego R, Tchernitchin A, Dorador C, Bolados A, Harrod C. 2018. Geologic and anthropogenic sources of contamination in settled dust of a historic mining port city in northern Chile: health risk implications. Peer J 6: e4699 DOI 10.7717/peerj.4699.

Tow SWT, Eng ZX, Wong SP, Ge L, Tan SN, Yong JWH. 2016. Axonopus compressus (Sw.) Beauv.: A potential biomonitor for molybdenum in soil pollution. International Journal of Phytoremediation 20: 1363-1368 DOI 10.1080/15226514.2016.1207599.

Wang B, Tian CH. 2000. The exploitation and utilization of Luanchuan molybdenum ore field. China Molybdenum Industry 24: 3-7.

Wang J, Wang X, Li JK, Zhang HX, Xia Y, Chen C, Shen Z.G, Chen YH. 2018. Several newly discovered Mo-enriched plants with a focus on Macleaya cordata. Environmental Science and Pollution Research 25: 26493-26503 DOI 10.1007/s11356-018-2641-7. 
$\begin{aligned} 509 & \text { Wang XX, Huang XH, Hu FJ, Zhu F, Liang HZ, Wang RJ, Chu JJ, Zhu YQ. } 2018 . \\ 510 & \text { Characteristics of } \mathrm{Pb}, \mathrm{Zn} \text { accumulation and foliar nutrient in four kinds of woody species. }\end{aligned}$

510

511

512

513

514

515

516

517

518

519

520

521

522

523

524

525

526

527

528

529

530

531

532

533

534

535

536

537

538

539

540

541

542

543

544

545

546

547 Journal of Central South University of Forestry \& Technology 38(6): 121-128.

Wang ZH, Liu XY, Qin HY. 2019. Bioconcentration and translocation of heavy metals in the soil-plants system in Machangqing copper mine, Yunnan Province, China. Journal of Geochemical Exploration 200: 159-166 DOI 10.1016/j.gexplo.2019.02.005.

Wang ZQ, Hong C, Wang K, Li YF, Feng LH. 2018. Spatial distribution and sources of heavy metals in natural pasture soil around copper-molybdenum mine in northeast China.

Ecotoxicology and Environmental Safety 154: 329-336 DOI 10.1016/j.ecoenv.2018.02.048.

Wei FS, Chen JS, Wu YY, Zheng CJ. 1991. Study on background value of soil environment in China. Chinese Journal of Environmental Science 12: 12-19.

Xue L, Liu JF, Shi, SQ, Wei Y, Chang EM, Gao M, Chen LZ, Jiang ZP. 2014. Uptake of heavy metals by native herbaceous plants in an antimony mine (Hunan, China). Clean-Soil Air Water 42: 81-87 DOI 10.1002/clen.201200490.

Xu ZQ, Ni SJ, Tuo XG, Zhang CJ. 2008. Calculation of heavy metals' toxicity coefficient in the evaluation of potential ecological risk index. Environmental Science and Technology 2: 112-115 DOI 10.3969/j.issn.1003-6504.2008.02.030.

Yu C, Xu S, Gang M, Chen G, Zhou L. 2011. Molybdenum pollution and speciation in Nver River sediments impacted with Mo mining activities in western Liaoning, Northeast China. International Journal of Environmental Research 5: 205-212 DOI 10.1111/j.17480361.2010.00355.x.

Yu CC, Zhao WT, Gao XF, Cheng SG, Xie D, Ma PT. 2018. Distribution characteristics and health risk assessment of metals in drinking water sources from the Luhun reservoir. Environmental Science 39: 89-98 DOI 10.13227/j.hjkx.201706022.

Yu CX, Peng B, Peltola P, Tang XY, Xie SR. 2012. Effect of weathering on abundance and release of potentially toxic elements in soils developed on lower Cambrian black shales, P. R. China. Environmental Geochemistry and Health 34: 375-390 DOI 10.1007/s10653-0119398-y.

Zahran HH. 1999. Rhizobium-legume symbiosis and nitrogen fixation under severe conditions and in an arid climate. Microbiology and molecular biology reviews: MMBR 63: 968-972 DOI 10.1128/MMBR.63.4.968-989.1999.

Zeng CY. 2017. Studies on the resistance and remediation potential of three legumes to $\mathrm{Cu}$ tailings. Master Thesis, Jiangxi University of Finance and Economics.

Zeng J, Han GL, Wu QX, Tang Y. 2019. Geochemical characteristics of dissolved heavy metals in Zhujiang River, Southwest China: spatial-temporal distribution, source, export flux estimation, and a water quality assessment. Peer J 7: e6578 DOI 10.7717/peerj.6578.

Zeng QD, Liu JM, Qin KZ, Fan HR, Chu SX, Wang YB, Zhou LL. 2013. Types, characteristics, and time-space distribution of molybdenum deposits in China. International Geology Review 55: 1311-1358 DOI 10.1080/00206814.2013.774195.

Peer) reviewing PDF | (2019:12:44130:1:2:NEW 8 Apr 2020) 
548 Zhang D, Zhou MZ, Xiong KN, Gu BQ, Yang Y. 2019. Preliminary risk assessment of 549 molybdenum in the soils and crops around the Ni-Mo polymetallic mining area in Songlin, 550 Zunyi, China. Environmental Chemistry 38: 1328-1338 DOI 10.11654/jaes.2018-0746.

551 Zhang ZZ, Wang XW, Zhang JF, Jiang GY, Fan QD. 2017. The prediction of molybdenum

552 mineral demand and supply in China. Acta Geoscientica Sinica 38: 66-76

553 DOI 10.3975/cagsb.2017.01.11.

554 


\section{Table $\mathbf{1}$ (on next page)}

The shared species and endemic species in the mining area and the unexploited area

Table 1 The shared species and endemic species in the mining area and the unexploited area 
1 Table 1:

2 The shared species and endemic species in the mining and the unexploited area.

\begin{tabular}{|c|c|c|c|}
\hline & & Mining & Unexploited \\
\hline \multirow{2}{*}{$\begin{array}{l}\text { Shared } \\
\text { species }\end{array}$} & Woody & \multicolumn{2}{|c|}{ Ailanthus altissima, Lespedeza bicolor, Robinia pseudoacacia } \\
\hline & Herbaceous & \multicolumn{2}{|c|}{$\begin{array}{l}\text { Artemisia argyi, Artemisia capillaris, Phragmites australis, Poa annua, Setaria viridis } \\
\text { Sorghum propinquum }\end{array}$} \\
\hline \multirow{2}{*}{$\begin{array}{l}\text { Endemic } \\
\text { species }\end{array}$} & Woody & $\begin{array}{l}\text { Amorpha fruticosa, Cotinus coggygria, } \\
\text { Euonymus alatus, Euonymus fortunei, } \\
\text { Ligustrum lucidum, Rosmarinus } \\
\text { officinalis, Salix linearifolia }\end{array}$ & $\begin{array}{l}\text { Albizia julibrissin, Indigofera tinctoria, } \\
\text { Juglans regia, Picrasma quassioides, Pinus } \\
\text { massoniana, Populus tomentosa, Quercus } \\
\text { acutissima, Toxicodendron vernicifluum }\end{array}$ \\
\hline & Herbaceous & $\begin{array}{l}\text { Asparagus cochinchinensis, Artemisia } \\
\text { sacrorum, Artemisia scoparia, } \\
\text { Ophiopogon japonicus, Panicum } \\
\text { bisulcatum, Picris hieracioides }\end{array}$ & $\begin{array}{l}\text { Artemisia annua, Artemisia selengensis, } \\
\text { Bidens pilosa, Dendranthema indicum, } \\
\text { Medicago falcata, Triarrhena sacchariflora }\end{array}$ \\
\hline
\end{tabular}

3

4

5

6 
Table 2 (on next page)

Soil heavy metal concentrations $\left(\mathrm{mg} \cdot \mathrm{kg}^{-1}\right)$ in the mining and the unexploited areas

Table 2 Soil heavy metal concentrations $\left(\mathrm{mg} \cdot \mathrm{kg}^{-1}\right)$ in the mining and the unexploited areas. Notes: Different letters after the values of each column represent significant difference at $P<0.05$ level, according to t-test. ${ }^{a}$ second-grade threshold of the Environmental Quality Standard for Soils in China (GB15618-1995). ${ }^{\text {b }}$ Soil background values of China (Wei et al., 1991). 
1 Table 2:

2 Soil heavy metal concentrations $\left(\mathrm{mg} \cdot \mathrm{kg}^{-1}\right)$ in mining and unexploited areas.

\begin{tabular}{ccccc}
\hline & $\mathrm{Mo}\left(\mathrm{mg} \cdot \mathrm{kg}^{-1}\right)$ & $\mathrm{Cu}\left(\mathrm{mg} \cdot \mathrm{kg}^{-1}\right)$ & $\mathrm{Mn}\left(\mathrm{mg} \cdot \mathrm{kg}^{-1}\right)$ & $\mathrm{Zn}\left(\mathrm{mg}^{-1} \mathrm{~kg}^{-1}\right)$ \\
\hline Mining & $268.13 \mathrm{a}$ & $136.45 \mathrm{a}$ & $1282.46 \mathrm{a}$ & $456.22 \mathrm{a}$ \\
Unexploited & $108.13 \mathrm{~b}$ & $63.80 \mathrm{~b}$ & $938.14 \mathrm{~b}$ & $370.70 \mathrm{~b}$ \\
Threshold & - & $\leq 100^{\mathrm{a}}$ & - & $\leq 300^{\mathrm{a}}$ \\
Background value & $2.00^{\mathrm{b}}$ & $22.60^{\mathrm{b}}$ & $583.00^{\mathrm{b}}$ & $74.20^{\mathrm{b}}$ \\
\hline
\end{tabular}

3 Notes:

4 Different letters after the values of each column represent significant difference at $\mathrm{P}<0.05$ level, according to T-test.

5 a second grade threshold of the Environmental Quality Standard for Soils in China (GB15618-1995).

6 b Soil background values of China (Wei et al., 1991). 


\section{Table 3(on next page)}

The potential soil ecological risk indexes of heavy metals in Luanchuan molybdenum mine area

Table 3 The potential soil ecological risk indexes of heavy metals in Luanchuan molybdenum mine area. Notes: The values in brackets represent the risk index of a single heavy metal as a percentage of the total risk index. 
1 Table 2:

2 The potential soil ecological risk indexes of heavy metals in Luanchuan molybdenum mine area.

\begin{tabular}{cccccc}
\hline \multirow{2}{*}{ Area } & \multicolumn{2}{c}{$\mathrm{E}_{\mathrm{i}}$} & \multicolumn{2}{c}{$\mathrm{Zn}$} & $\mathrm{Z}$ \\
\cline { 2 - 5 } & $\mathrm{Mo}$ & $\mathrm{Cu}$ & $\mathrm{Mn}$ & 2049.45 \\
Mining & $2010.98(98.12 \%)$ & $30.19(1.47 \%)$ & $2.20(0.11 \%)$ & $6.15(0.30 \%)$ & $200 \%)$ \\
Unexploited & $810.97(97.54 \%)$ & $14.12(1.70 \%)$ & $1.61(0.19 \%)$ & $5.00(0.60 \%)$ & 831.39 \\
\hline
\end{tabular}

3 Note:

4 The values in brackets represent the risk index of a single heavy metal as a percentage of the total risk index. 
Figure 1

Mo concentration of plants growing in the mining and the unexploited areas.

Figure 1. Mo concentration of plants growing in the mining and the unexploited areas. Values represent mean \pm standard error $(\mathrm{SE})$, the same as below. * above bars indicate significant differences between the same organs in plants for different areas at $P<$ 0.05 , according to the t-test. 


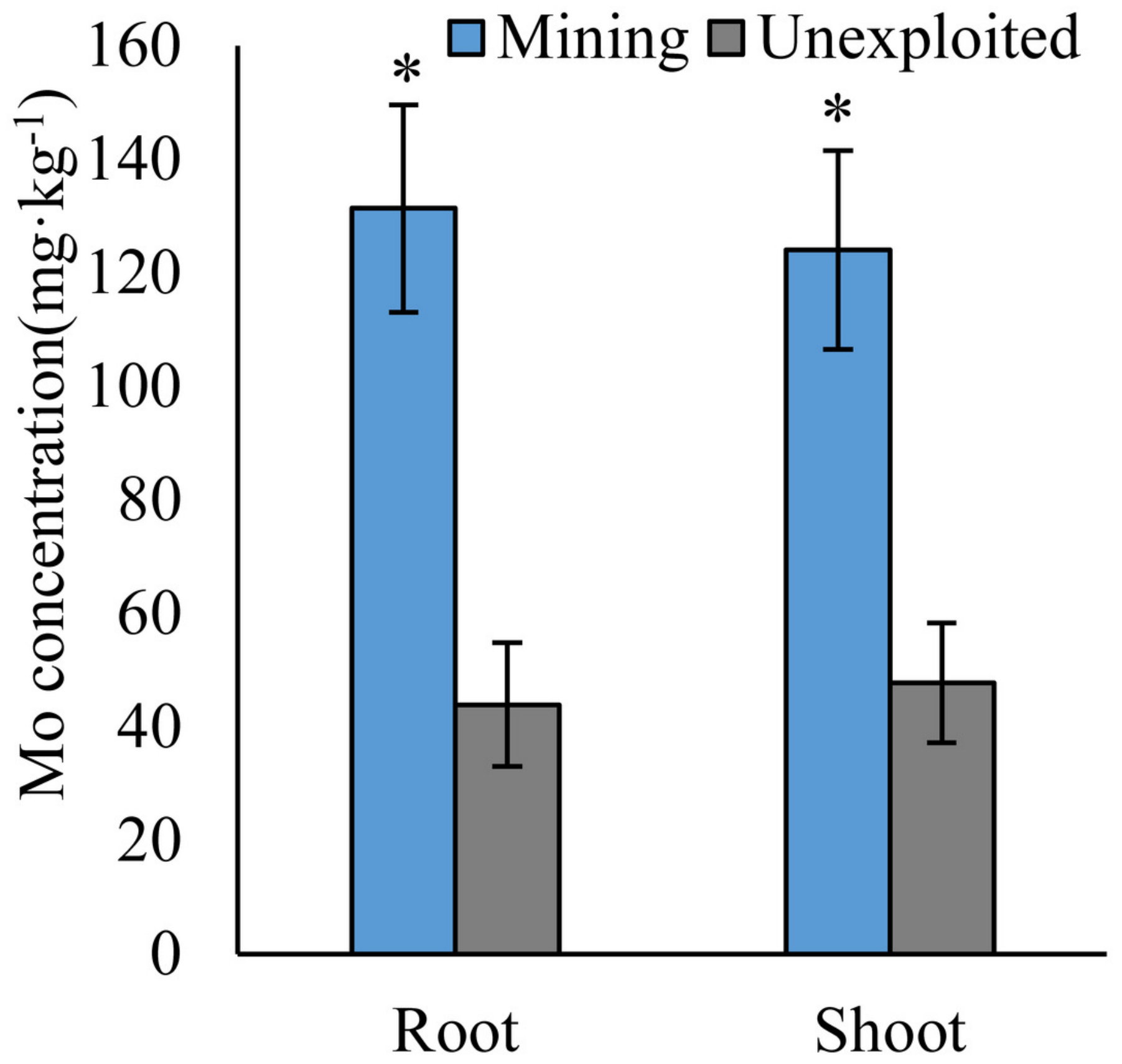


Figure 2

Mo concentration of different life forms of plants growing in the mining and the unexploited areas.

Figure 2. Mo concentration of different life forms of plants growing in the mining and the unexploited areas. * above bars indicate significant differences between the same organs in the same plant life forms for different areas at $P<0.05$, according to the ttest. 


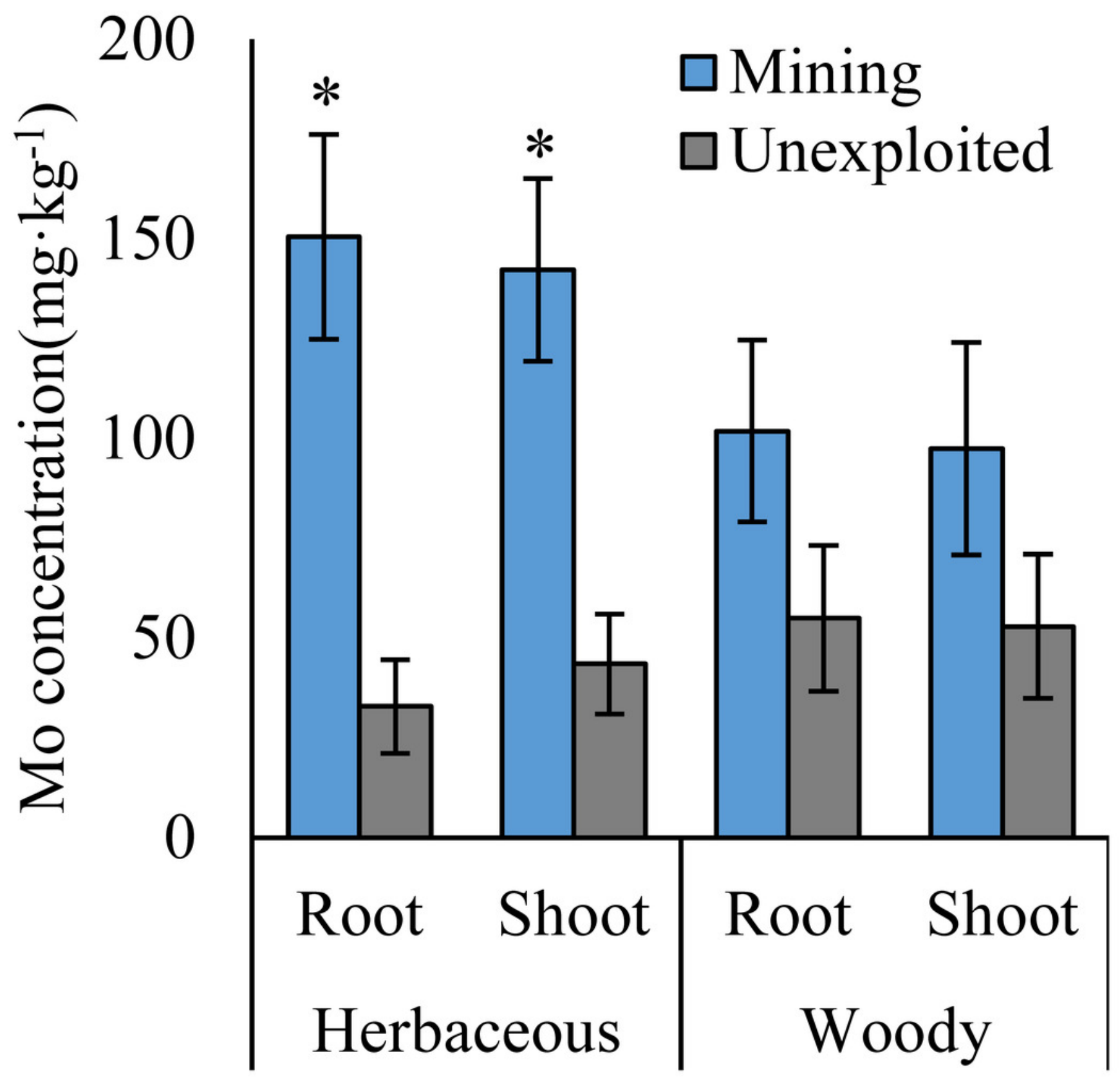


Figure 3

Mo concentration of dominant species growing in the mining and the unexploited areas.

Figure 3. Mo concentration of dominant species growing in the mining and the unexploited areas. * above bars indicate significant differences between the same organs in the same species for different areas at $P<0.05$, according to the t-test. 


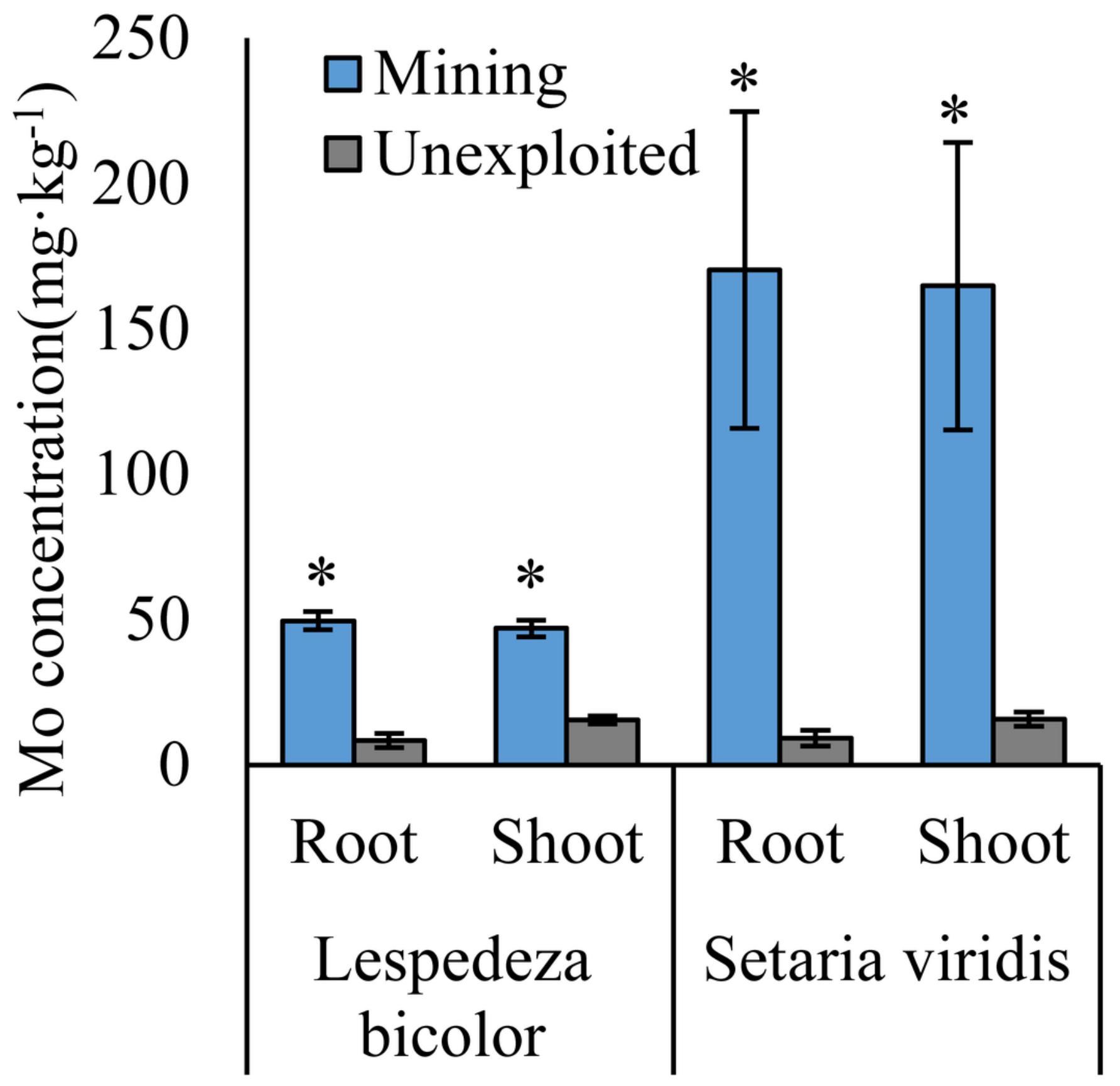


Figure 4

Mo translocation of plants growing in the mining and the unexploited areas.

Figure 4. Mo translocation of plants growing in the mining and the unexploited areas. * above bars indicate significant differences between the plants for different areas at $P<0.05$, according to the t-test. 


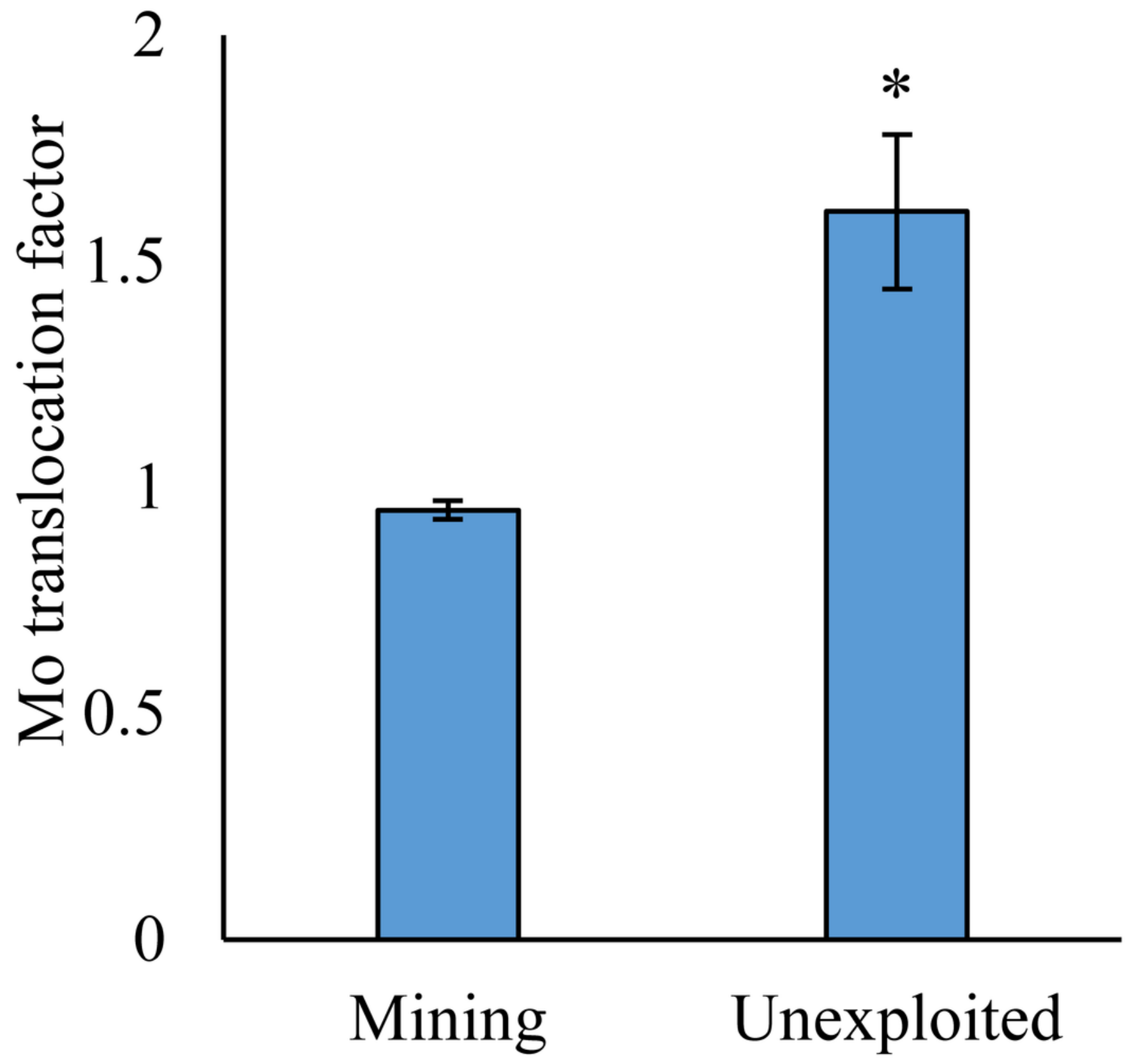


Figure 5

Mo translocation of different life forms of plants growing in the mining and the unexploited areas.

Figure 5. Mo translocation of different life forms of plants growing in the mining and the unexploited areas. * above bars indicate significant differences between the same organs in the same plant life forms for different areas at $P<0.05$, according to the ttest. 


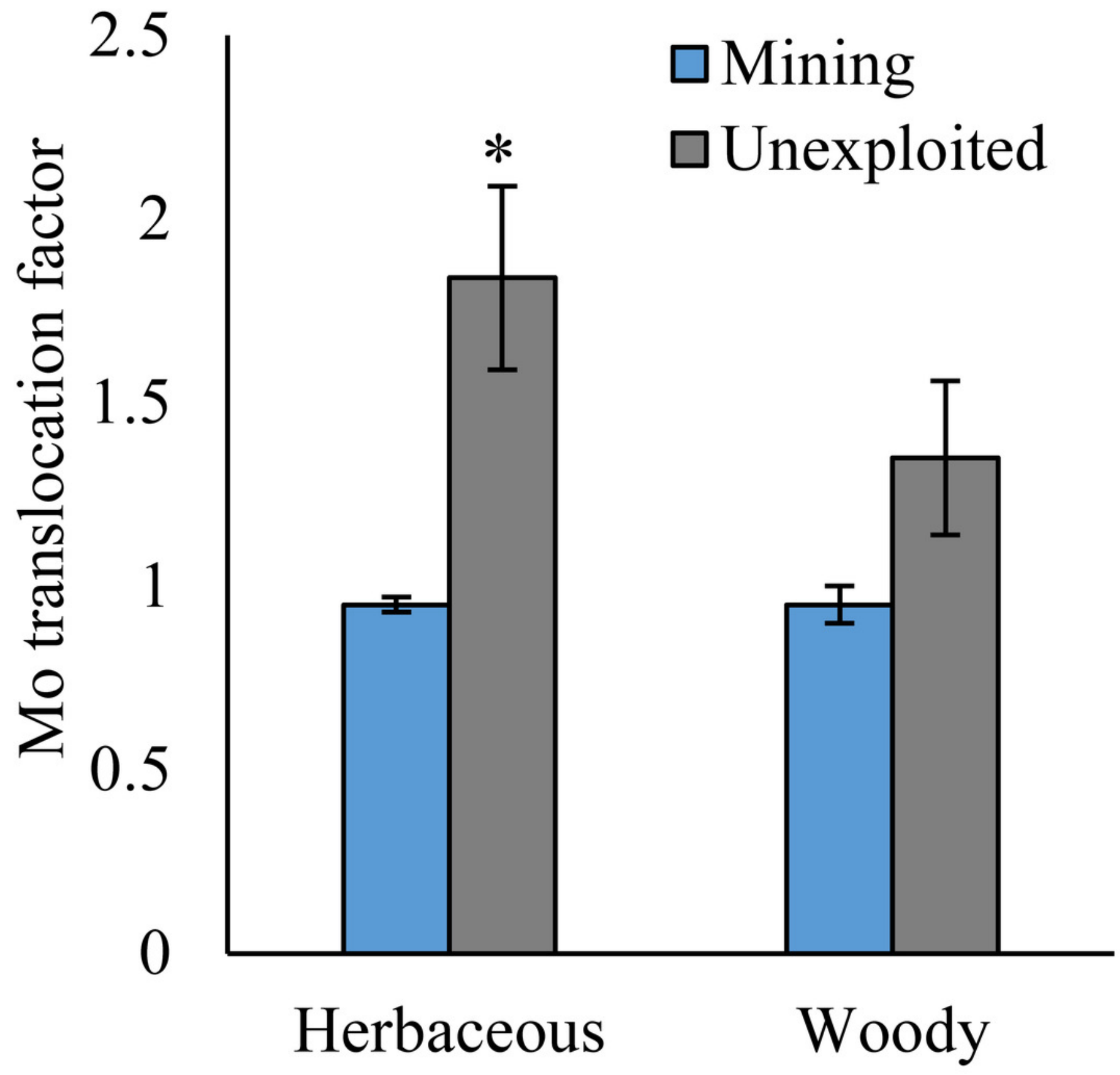


Figure 6

Mo translocation of dominant species growing in the mining and the unexploited areas.

Figure 6. Mo translocation of dominant species growing in the mining and the unexploited areas. * above bars indicate significant differences between the same organs in the same species for different areas at $P<0.05$, according to the t-test. 


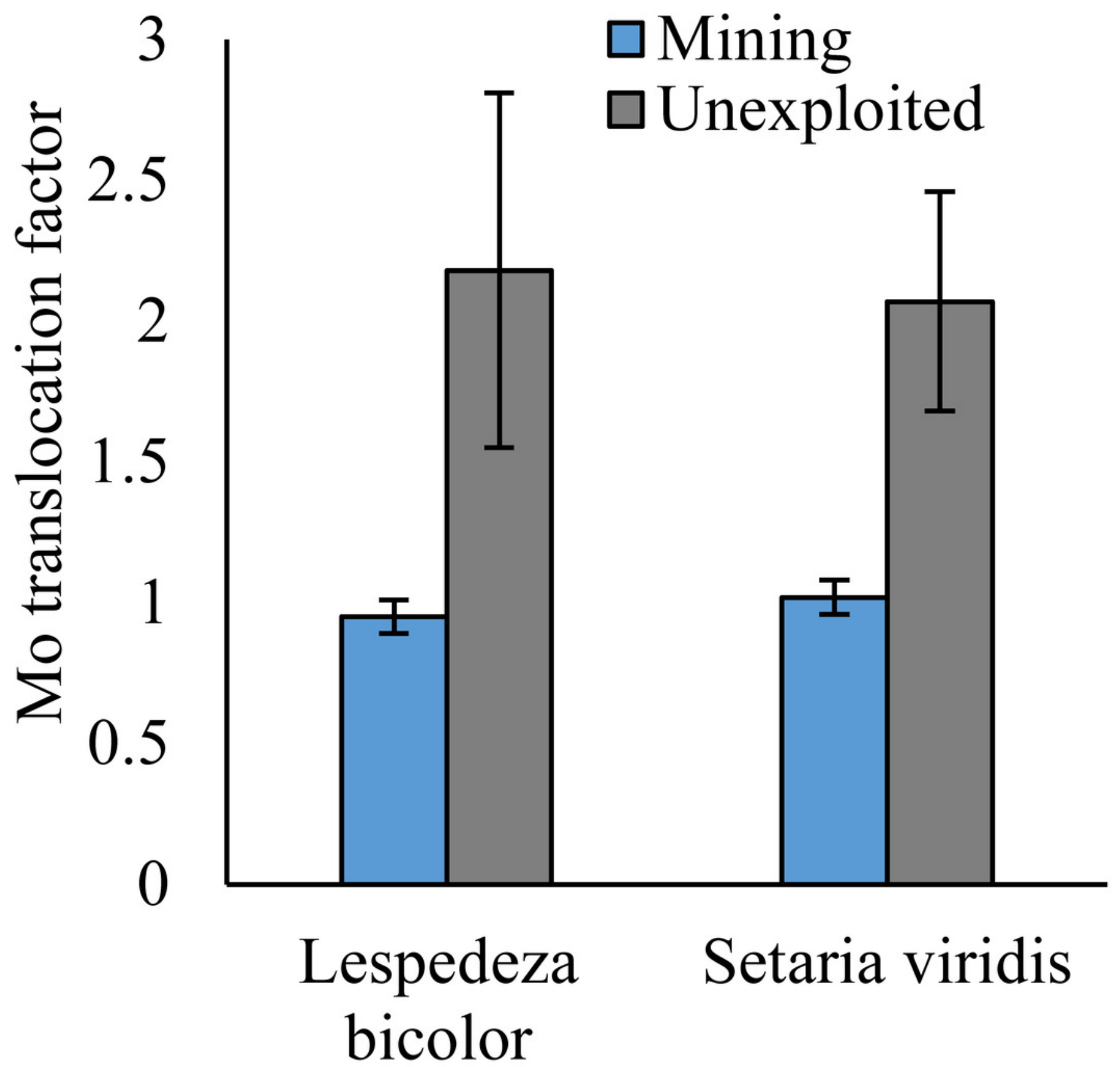


Figure 7

The relationship between shoot Mo and root Mo in plants.

The relationship between shoot Mo and root Mo in plants. (a) Mining area; (b) Unexploited area.
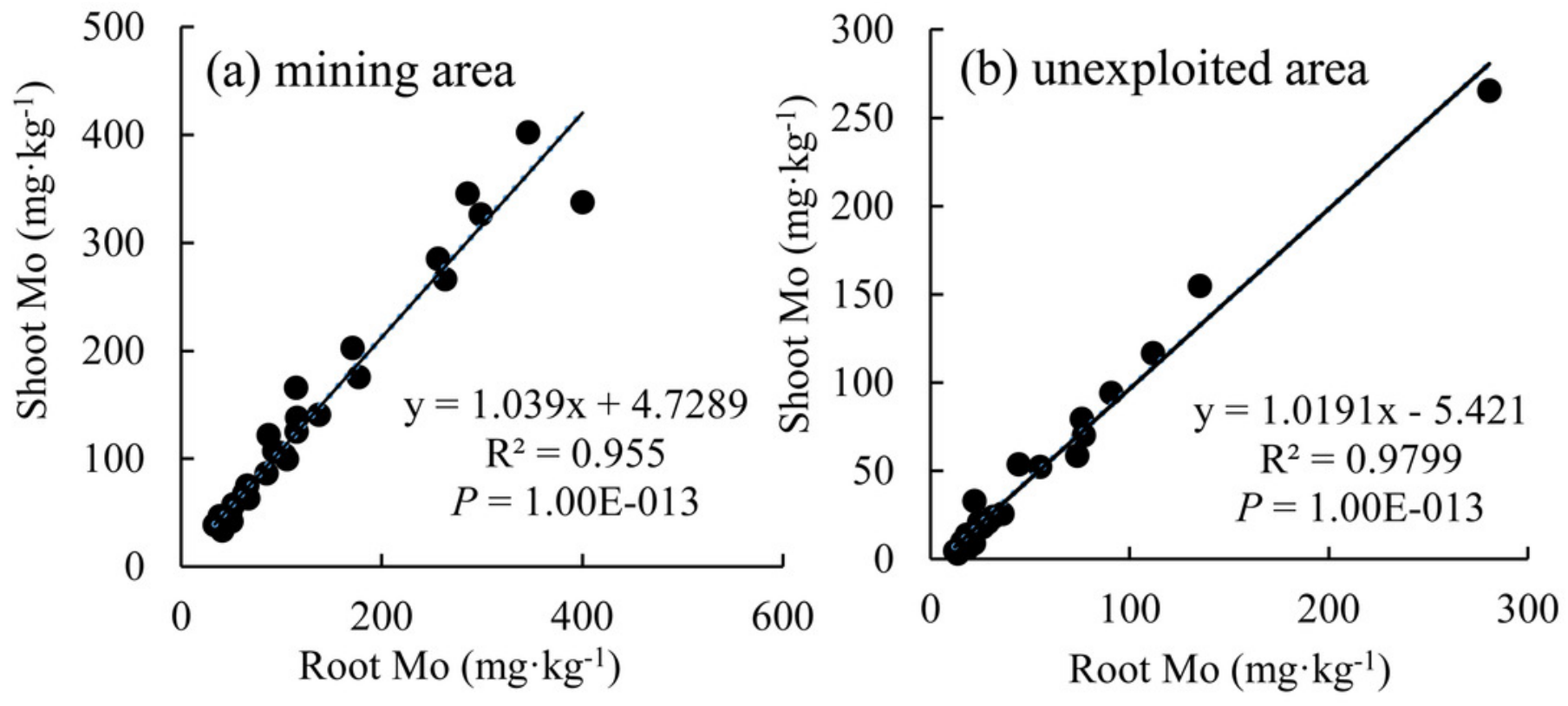